\title{
Contraceptive effect of Uncaria tomentosa (cat's claw) in rats with experimental endometriosis $^{1}$
}

\author{
Efeito anticoncepcional da Uncaria tomentosa (unha-de-gato) em ratas com endometriose \\ experimental
}

\begin{abstract}
João Nogueira Neto', Frederico Lucas Lima Paiva Cavalcante ${ }^{\text {II }}$, Rafael Antonio Freire Carvalho ${ }^{\text {II }}$, Taciana Gabrielle Pinheiro de Moura Rodrigues II, Mariana Santana XavierII, Pablo Gustavo Ribeiro Furtado ${ }^{I I I}$, Eduardo Schor ${ }^{\text {IV }}$

IFellow PhD degree, Federal University of Sao Paulo (UNIFESP) and Unit of Endometriosis and Surgical Laboratory, HU-UFMA, Maranhao, Brazil. Designed the protocol, involved with technical procedures, responsible for manuscript writing, responsible for intellectual and scientific content of the study, supervised all phases of the study, provided guidelines for the surgical intervention.

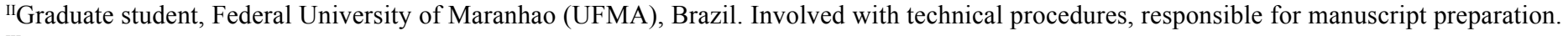
IIIMD, Pathology Department, HU-UFMA, Maranhao, Brazil. Macroscopic and histopathological examinations.

${ }^{I V}$ PhD, Affiliate Professor, UNIFESP, Sao Paulo and Head of Unit of Pelvic Pain and Endometriosis of Paulista School of Medicine (EPM-UNIFESP), Brazil. Responsible for acquisition and interpretation of data, helped with technical procedures, provide guidelines for the surgical interventions.
\end{abstract}

\begin{abstract}
PURPOSE: Evaluate the histological changes in parenchyma's epithelial layer of the uterus and ovarian of rats with induced endometriosis, treated with Uncaria tomentosa extract.

METHODS: 29 rats with experimental endometriosis, were selected and divided in three groups: The uncaria group received $32 \mathrm{mg} / \mathrm{ml}$ of Uncaria tomentosa extract, $1 \mathrm{ml}$ administered daily and the placebo group received $1 \mathrm{ml}$ of saline $0.9 \%$ per day, during for 14 days (both groups); the leuprolide group received leuprolide acetate $1 \mathrm{mg} / \mathrm{kg}$ body weight applied single subcutaneous dose. In the $15^{\text {th }}$ day of treatment the uterine horn and ovaries were removed for histopathological analysis.

RESULTS: The uncaria group presented nine samples (90\%) with immature ovarian follicles, whereas the placebo group did not present any case and in the leuprolide group there were eight rats $(88 \%)$ with the same change. The placebo group showed mature corpus luteum in all animals, occurring less frequent in uncaria (10\%) and leuprolide (22\%) groups. The uterine epithelium showed weak proliferative in nine (90\%) samples of the uncaria group, in two (20\%) animals in the placebo group and seven (77.8\%) rats in the leuprolide group.
\end{abstract}

CONCLUSIONS: The findings suggest that Uncaria tomentosa has contraceptive effect.

Key words: Endometriosis. Phytotherapy. Contraception. Rats.

\section{RESUMO}

OBJETIVO: Avaliação histológica do útero e parênquima ovariano de ratas com endometriose induzida tratadas com extrato de Uncaria tomentosa.

MÉTODOS: Foram selecionadas 29 ratas com endometriose experimental e formados três grupos: O grupo uncaria recebeu extrato de Uncaria tomentosa com $32 \mathrm{mg} / \mathrm{ml}$, administrado $1 \mathrm{ml}$ ao dia e o grupo placebo recebeu $1 \mathrm{ml}$ de solução salina a $0,9 \%$, ambos por 14 dias; o grupo leuprolida recebeu acetato de leuprolida $1 \mathrm{mg} / \mathrm{kg}$ de peso corporal aplicado via subcutânea dose única. No $15^{\circ}$ dia de tratamento realizou-se retirada de corno uterino e ovários para análise histopatológica.

RESULTADOS: O grupo uncaria apresentou nove amostras (90\%) com maturação incompleta dos folículos ovarianos, já o grupo placebo não apresentou nenhum caso e no grupo leuprolida houve oito ratas (88\%) com a mesma alteração. O grupo placebo apresentou corpo lúteo maduro em todos os animais, acontecendo de forma menos freqüente nos grupos uncaria (10\%) e leuprolida $(22 \%)$. O epitélio uterino se mostrou fracamente proliferativo em nove (90\%) das amostras do grupo unacaria, em dois (20\%) casos do grupo placebo e sete $(77.8 \%)$ casos no grupo leuprolida.

CONCLUSÃO: Os achados sugerem que a Uncaria tomentosa tem efeito anticoncepcional.

Descritores: Endometriose. Fitoterapia. Anticoncepção. Ratos. 


\section{Introduction}

Endometriosis is a disease characterized by the presence of tissue that is structurally and functionally similar to the endometrial tissue outside the uterine cavity, which affects the quality of life and reproductive capacity of patients. Usually develops in the pelvic organs such as the peritoneum, ovaries, fallopian tubes, uterus and fornix Douglas ${ }^{1,2}$.

The incidence of endometriosis is as high as around 10\% of women in reproductive age. This pathology behaves like an estrogen responsive disease with inflammatory and immunomodulatory activities, as well as imbalance of cellular apoptosis and oxidative stress ${ }^{2-5}$.

The treatment of endometriosis can be surgical or clinical, whose usual medication therapy is one that interferes on the normal menstrual cycle inducing pseudopregnancy, pseudomenopause or chronic anovulation, providing clinical improvement. However its effects are not curative, with frequent recurrences, which justify the search for new treatments ${ }^{6}$.

The Uncaria tomentosa, popularly known as cat's claw, belongs to the Rubiaceae family, commonly found in tropical areas of South and Central America. This plant, in the form of extract, is widely used by indigenous people and is often used as an alternative treatment for various diseases. Studies have shown that cat's claw has anti-inflammatory, immunomodulatory, pro-apoptotic and antioxidant, as well as contraceptive effect, to justify a possible alternative to treat endometriosis ${ }^{7,8}$.

The aim of this study was to evaluate the histological changes in parenchyma's epithelial layer of the uterus and ovarian of rats with induced endometriosis, treated with Uncaria tomentosa aqueous extract (cat's claw).

\section{Methods}

This experimental study was completed between April and May 2011, with a sample of 40 Wistar rats (Rattus norvegicus albinos) adult, females, virgin, weighing between 180 and 250 grams, with 60 days of age, provided by the Bioterium of the Federal University of Maranhão (UFMA).

This research was performed at Experimental Surgery Laboratory of the University Hospital of the Federal University of Maranhão. It followed the Brazilian legislation for the use of experimental animals (Arouca Law No. 11,794 / 2008) and the standards set by the Brazilian College of Animal Experimentation (COBEA), an institution affiliated with the International Council for Laboratory Animal Science. The study was approved by the Animal Experimentation Ethics Committee (CEEA-UEMA) under protocol number 011/2011.

The animals were grouped five per polypropylene cage with stainless steel grill cover, measuring $46 \mathrm{~cm}$ x $31 \mathrm{~cm}$ x $16 \mathrm{~cm}$ with the bottom covered with wood shavings, changed every 48 hours. The animals were kept under constant environmental conditions, receiving rat chow (Purina ${ }^{\circledR}$, São Paulo, Brazil) and water ad libitum seven days for adaptation, with noise control, temperature $22^{\circ} \mathrm{C} \pm 2{ }^{\circ} \mathrm{C}$, relative humidity $40 \% 60 \%, 12 / 12$ hours light /dark cycle.

The induction of endometriosis was performed according to the methodology proposed by Nogueira Neto et al. ${ }^{9}$. After 21 days since the first surgery, the rats underwent further surgery again, at which time was made the inventory of the peritoneal cavity with identification and measurement of the autotransplantation focus with a digital pachymeter, followed by calculating the volume using the Degree Classification System of Growth Implants in accordance with Quereda et al. ${ }^{10}[4 \pi$ (length / 2) x (width / 2) x (height / 2) / 3]. Only those that have developed level of growth two and three remained in the study.

The rats were randomly divided into three groups. Each animal was marked on the tail with four mm permanent brush (Pilot ${ }^{\circledR}$, São Paulo, Brazil) and the cages were identified. The beginning of gavage was from 22 post-surgical day of endometriosis induction.

The groups were divided as follows: group Uncaria received gavage with $32 \mathrm{mg} / \mathrm{ml}$ Uncaria tomentosa extract (Cat's Claw 100mg, Herbarium of Brazil), administered $1 \mathrm{ml}$ per day, and the placebo group received daily gavage with $1 \mathrm{ml}$ of saline $0.9 \%$, both for 14 days according Nogueira Neto et al. ${ }^{9}$. The group leuprolide received leuprolide acetate $1 \mathrm{mg} / \mathrm{kg}$ of body weight (Lupron $^{\mathrm{TM}} 3,75 \mathrm{mg}$, ABBOTT of Brazil) single subcutaneous dose $^{11}$.

The experimental drug is composed of $16 \mathrm{~g}$ of cat's claw extract (Uncaria tomentosa) and $500 \mathrm{ml}$ of $0.9 \%$ saline solution. The processing was done by grinding 160 tablets of $100 \mathrm{mg}$ of cat's claw extract (Cat's Claw $100 \mathrm{mg}$, Herbarium of Brazil) in a porcelain mortar with a pestle, and then proceeding with the dissolution of it in $500 \mathrm{ml} 0.9 \% \mathrm{NaCl}$ in a beaker to mix until smooth. The mixture was made in an average time of 15 minutes, and the total volume was $500 \mathrm{ml}$ in suspension with a $32 \mathrm{mg} / \mathrm{ml}$ concentration ${ }^{9}$.

After the end of treatment, a new surgery was done and, at this time, the inventory of the peritoneal cavity was made again. The remaining right uterine horn and both ovaries were removed for histological evaluation. The parts removed were cleaned with $0.9 \%$ saline solution and stored in container with $10 \%$ buffered formalin, receiving identification and forwarded to the Pathology Department of the University Hospital of the Federal University of Maranhão. Tissue sections were made and stained with hematoxylin-eosin (HE).

The animals in each group were killed on the 15 th day after the beginning of treatment. After weight, they have been given $150 \mathrm{mg} / \mathrm{kg}$ of sodium thiopental (Thiopental ${ }^{\circledR}$, Crystal, St. Paul) through the intraperitoneal administration. The drug was diluted in equal volume of saline, according to resolution Number 714, June 20, 2002, Federal Council of Veterinary Medicine (CFMV). Death was characterized by cardio-respiratory arrest and complete absence of reflexes.

Data analysis was descriptive, based on the histological findings according to Mukherji and Bhowmik ${ }^{12}$. 


\section{Results}

From the initial sample of 40 rats, ten were excluded for not developing endometriosis grades two and three, and one due to aspiration during gavage. The final sample was composed for 29 rats, being divided in three groups: uncaria and placebo, both with ten animals; and leuprolide group with nine rats.

The group undergoing treatment with Uncaria tomentosa (Uncaria group) revealed immature follicles (Table 1 and Figure 1) in nine cases $(90 \%)$, and the follicles with full maturation and mature corpus luteum (Table 2) is present in one case $(10 \%)$.

TABLE 1 - Ovarian follicle histological analysis of the placebo, uncaria and leuprolide groups

\begin{tabular}{cccc}
\hline $\begin{array}{c}\text { Ovarian follicle } \\
\text { histological analysis }\end{array}$ & $\begin{array}{c}\text { Placebo } \\
\text { group }\end{array}$ & $\begin{array}{c}\text { Uncaria } \\
\text { group }\end{array}$ & $\begin{array}{c}\text { Leuprolida } \\
\text { group }\end{array}$ \\
\hline Mature & 10 & 01 & 00 \\
Primary & 00 & 09 & 09 \\
Total & 10 & 10 & 09 \\
\hline
\end{tabular}

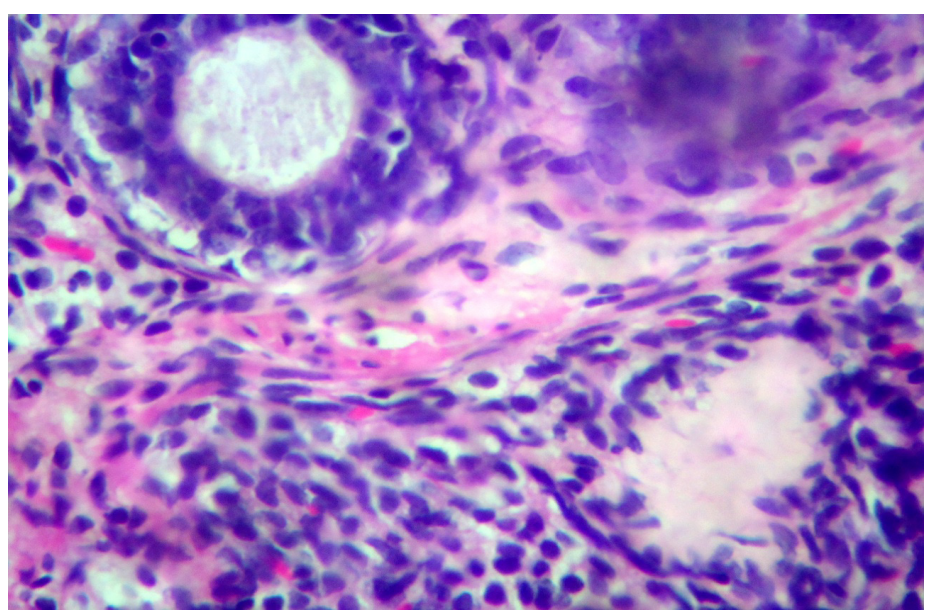

FIGURE 1 - Photomicrograph showing primary follicles in ovarian stromal area of an Uncaria Group sample. Displays corpus albicans (hematoxylin-eosin, 400x)

TABLE 2 - Corpus luteum histological analysis of the placebo, uncaria and leuprolide groups

\begin{tabular}{cccc}
\hline $\begin{array}{c}\text { Corpus luteum } \\
\text { histological analysis }\end{array}$ & $\begin{array}{c}\text { Placebo } \\
\text { group }\end{array}$ & $\begin{array}{c}\text { Uncaria } \\
\text { group }\end{array}$ & $\begin{array}{c}\text { Leuprolide } \\
\text { group }\end{array}$ \\
\hline Absent & 00 & 02 & 01 \\
Atrophied & 00 & 07 & 08 \\
Mature & 10 & 01 & 00 \\
Total & 10 & 10 & 09 \\
\hline
\end{tabular}

The uterine histology (Table 3) showed weakly proliferative endometrium (Figure 2) in nine samples (90\%).
TABLE 3 - Epithelial uterus layer of rats histological analysis of placebo, leuprolide and uncaria groups

\begin{tabular}{cccc}
\hline $\begin{array}{c}\text { Epithelial uterus layer } \\
\text { histological analysis }\end{array}$ & $\begin{array}{c}\text { Placebo } \\
\text { group }\end{array}$ & $\begin{array}{c}\text { Uncaria } \\
\text { group }\end{array}$ & $\begin{array}{c}\text { Leuprolida } \\
\text { group }\end{array}$ \\
\hline Atrophied & 00 & 00 & 02 \\
weakly proliferative & 02 & 09 & 07 \\
Proliferative & 08 & 01 & 00 \\
Total & 10 & 10 & 09 \\
\hline
\end{tabular}

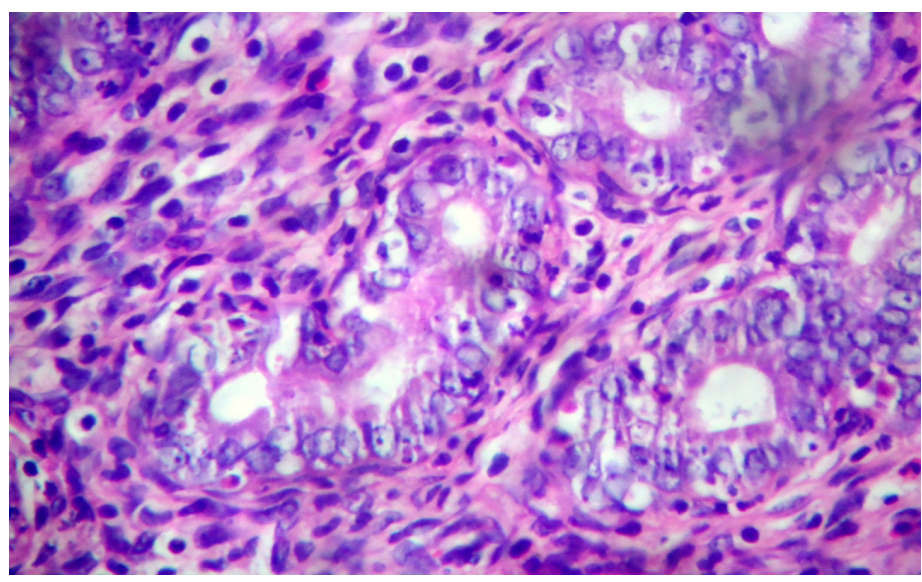

FIGURE 2 - Weakly proliferative endometrium of an Uncaria Group sample. Presents a greater number of glandular structures, characterized by a slight increase in its lumen, nuclear stratification, presence of mitoses and apoptotic bodies. (Hematoxylin-eosin, 400x)

The placebo group had follicles with full maturation and mature corpus luteum in all cases $(100 \%)$. In relation to the endometrium, it was proliferative in eight cases $(80 \%)$.

The leuprolide group had immature follicles in all samples and atrophied corpus luteum in eight samples (88\%). The endometrium was atrophied (Figure 3 ) in two cases $(22.2 \%)$, and weakly proliferative in seven cases $(77.8 \%)$.

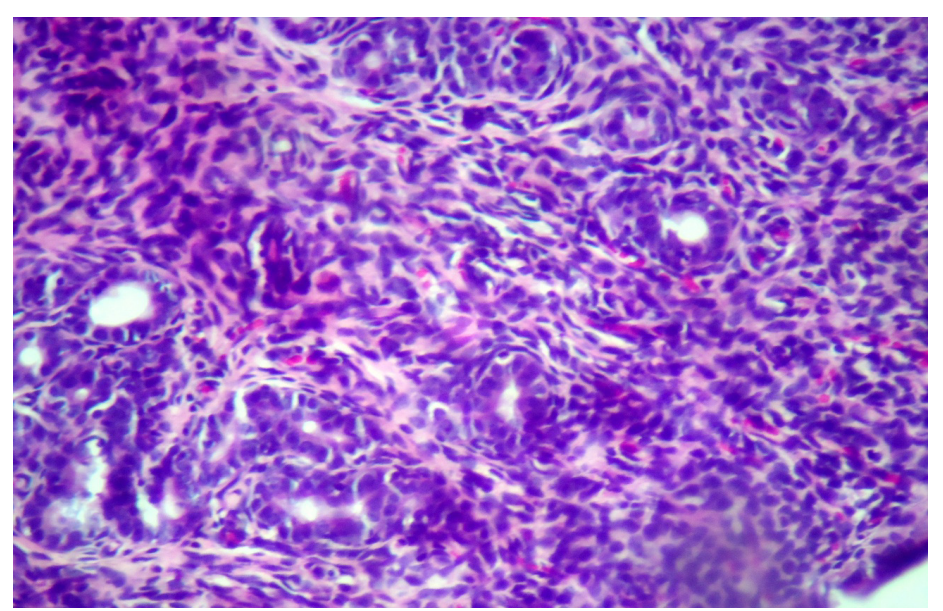

FIGURE 3 - Atrophic endometrium of a leuprolide group sample. Presents small number of glands, small size, no stratification or nuclear epithelial proliferation (hematoxylin-eosin, 200x) 


\section{Discussion}

Studies with clinical and experimental data about the use of medicinal herbs to treat endometriosis, reported that several drugs with anti-inflammatory, analgesic, immunomodulatory and antioxidants properties are effective in combating this disease. New clinical studies about the effectiveness of herbs are necessary for the treatment of endometriosis in women ${ }^{13}$. In this sense, the evidence guide for the endometriosis diagnosis and treatment conducted by the European Society of Human Reproduction and Embryology, consider a recommendation degree of grade D for the use of medicinal herbs in the treatment of endometriosis, that is, there is no evidence to support these treatments, but this society recommends that herbal medicines should not be discarded because in some women that used this herbs has been noticed a decreased of pain and improved quality of life. In addition, we have the fact that cat's claw has already authorized its use by institutions like the FDA (Food and Drug Administration) as a food supplement.

The endometriosis knowledge about physiopathology with inflammatory changes, apoptotic, immunomodulatory and antioxidant, gave foundation to use drugs, experimentally, that possess action mechanisms with adverse effects of these changes mentioned above. An Experimental study using this extract showed significant reduction of endometrial focus 9 .

Once established that the cat's claw reduces endometriosis experimentally, it is necessary to evaluate the Uncaria tomentosa action mechanism for the treatment of this pathology. Among the drugs commonly used to treat endometriosis are the contraceptives, with known action against endometriosis. In the evaluation in vitro culture of the mammary tumor tissue (infiltrating ductal carcinoma, stage II and poorly differentiated) was used Uncaria tomentosa and compared with methotrexate, where it was observed decrease in specific area of estrogen receptors caused by this herbal medicine, which attributes a contraceptive action to Uncaria tomentos $a^{15}$. Based on this premise has become necessary to evaluate the contraceptive effect of cat's claw.

The histological parameter chosen to evaluate the contraceptive effects was made based on a study that examined the use of intramuscular medroxy-progesterone in rats with different doses, followed by histological analysis of ovaries and uterus epithelial layer of the sample ${ }^{12}$. They were organized into three groups, experimental, positive and negative controls. The experimental group (Uncaria group) made use $32 \mathrm{mg}$ /day of Uncaria tomentosa extract and the negative control group (Placebo group) used daily $1 \mathrm{ml}$ of saline $0.9 \%$ based on Neto et al. ${ }^{9}$, which showed significant reduction of endometriosis with no clinical complications apparent. The positive control group (leuprolide group) received leuprolide acetate $1 \mathrm{mg} / \mathrm{kg}$ of body weight applied single subcutaneous dose, based on Oktem et al. ${ }^{11}$, which evaluated the use of high dose of atorvastatin on experimental endometriosis with satisfactory results ${ }^{11}$. The leuprolide acetate is a GnRH analogue, which has excellent results in women whit endometriosis, but has limited use due to side-effects, mainly characterized by bone loss and climacteric complaints ${ }^{14}$.

Histological analysis of ovaries showed similar changes in uncaria and leuprolide groups, showing an absence of atrophy of corpus luteum and primary ovarian follicles, in most samples, which suggests the absence of ovarian activity. In histological evaluation of the uterine epithelial layer, Uncaria and leuprolide groups again performed similarly, with their samples showed weakly proliferative epithelial layers, contrary to that observed in the placebo group with all their samples in the proliferative phase. These data according to Mukherji and Bhowmik ${ }^{12}$ are compatible with contraception.

\section{Conclusion}

Considering the histopathological findings in rats with experimental endometriosis exposed to the extract of Uncaria tomentosa and compared with positive and negative control groups, we suggest that the changes found are compatible with contraception.

\section{References}

1. Sampson J. Peritoneal endometriosis due to menstrual dissemination of endometrial tissue into the peritoneal cavity. Am J Obstet Gynecol. 1927; 14:442-69.

2. Banu SK, Starzinski-Powitz A, Speights VO, Burghardt RC, Arosh JA. Induction of peritoneal endometriosis in nude mice with use of human immortalized endometriosis epithelial and stromal cells: a potential experimental tool to study molecular pathogenesis of endometriosis in human. Fertil Steril. 2009;91:2199-209.

3. Vignali M, Infantino M, Matrone R, Chiodo I, Somigliana E, Busacca M, Viganò P. Endometriosis: novel etiopathogenetic concepts and clinical perpectives. Fertil Steril. 2002;78:665-78.

4. Braun PD, Ding J, Shen J, Rana N, Fernandez BB, Dmowski WP. Relationship between apoptosis and the number of macrophages in eutopic endometrium from women with and without endometriosis. Fertil Steril. 2002;78:830-5.

5. Van Langendonckt A, Casanas-Roux F, Donnez J. Oxidative stress and peritoneal endometriosis. Fertil Steril. 2002;77:861-70.

6. Olive DL, Pritts AE. Treatment of endometriosis. N Engl J Med. 2001;345:266-75.

7. Allen-Hall L, Cano P, Arnason JT, Rojas R, Lock O, Lafrenie RM. Treatment of THP-1 cells with Uncaria tomentosa extracts differentially regulates the expression if IL-1ß and TNF- $\alpha$. J Ethnopharmacol. 2007;109:312-7.

8. Kuras M, Nowakowska J, Sliwinska E, Pilarski R, Ilasz R, Tykarska T, Zobel A, Gulewicz K. Changes in chromosome structure, mitotic activity and nuclear DNA content from cells of Allium Test induced by bark water extract of Uncaria tomentosa (Wild) DC. J Ethnopharmacol. 2006;107:211-21.

9. Nogueira Neto J, Coelho TM, Aguiar GC, Carvalho LR, Araújo AG, Girão MJ, Schor E. Experimental endometriosis reduction in rats treated with Uncaria tomentosa (cat's claw) Extract. Eur J Obstet Gynecol Reprod Biol. 2011;154:205-8.

10. Quereda F, Barroso J, Acien P. Individual and combined effects of triptoreline and gestrinone on experimental endometriosis in rat. Eur $\mathrm{J}$ Obstet Gynecol Reprod Biol.1996;67:35-40.

11. Oktem M, Esinler L, Eroglu D, Haberal N, Bayraktar N, Zeyneloglu HB. High-dose atorvastatin causes regression of endometriotic implants: a rat model. Hum Reprod. 2007;22:1474-80.

12. Bhowmik T, Mukherjea M. Histological changes in the ovary and uterus of rat after injectable contraceptive therapy. Contraception. 1988;37:529-38.

13. Wieser F, Cohen M, Gaeddert A, Yu J, Burks-Wicks C, Berga SL, Taylor RN. Evolution of medical treatment for endometriosis: back to the roots? Hum Reprod. 2007;13:487-99. 
14. Kennedy S, Bergqvist A, Chapron C, D’Hooghe T, Dunselman G, Greb R, Hummelshoj L, Prentice A, Saridogan E. ESHRE guideline for the diagnosis and treatment of endometriosis. Hum Reprod. 2005;20:2698-704.
15. Salazar E, Jayme V. Depletion of Specific Binding Sites for Estrogen Receptor by Uncaria tomentosa. Proc Western Pharmacol Soc. 1998;41:123-4.

\section{Correspondence:}

João Nogueira Neto

Av. dos Holandeses S/N Qd 24 Lote 05/901

65071-380 - São Luís - MA Brazil

j.nogueira.n@uol.com.br

Conflict of interest: none

Financial source: none

${ }^{1}$ Research performed at Experimental Surgery Laboratory, University Hospital, Federal University of Maranhao (LACEMA-HUUFMA), Brazil.

Presented at the XII National Congress on Experimental Surgery of the Brazilian Society for Development of Research in Surgery-SOBRADPEC, October 2011 26-29 Ribeirao Preto-SP, Brazil. 